\title{
Study of internal mammary sentinel lymph node biopsy in breast cancer patients after neoadjuvant chemotherapy
}

\author{
Xiao-Shan $\mathrm{Cao}^{1,2}$ \\ Bin-Bin Cong ${ }^{1,2}$ \\ Xiao Sun' \\ Peng-Fei Qiu' \\ Yong-Sheng Wang' \\ 'Breast Cancer Center, Shandong \\ Cancer Hospital and Institute, Jinan, \\ Shandong, People's Republic of China; \\ ${ }^{2} S c h o o l$ of Medicine and Life Sciences, \\ Jinan University-Shandong Academy \\ of Medical Sciences, Jinan, Shandong, \\ People's Republic of China
}

This article was published in the following Dove Press journal:

OncoTargets and Therapy

9 October 2015

Number of times this article has been viewed

\section{Dear editor}

Internal mammary lymph node (IMLN) metastasis has a similar prognostic importance as axillary lymph nodal involvement in breast cancer patients. ${ }^{1}$ Patients with both axillary- and internal mammary-positive nodes have a very poor prognosis. ${ }^{2}$ Reliable data for internal mammary nodal metastases are reported to be present in $18 \%-33 \%$ (mean 23.4\%) of patients who have not been treated with neoadjuvant chemotherapy (NAC) mostly concomitant with axillary metastases, and metastases exclusively situated in the internal mammary chain occur in $2 \%-11 \%$ of patients, ${ }^{3}$ but limited data are available in the context of NAC.

Current imaging techniques, such as positron emission tomography/computed tomography, ultrasound, and magnetic resonance imaging, could usually detect metastases lesions larger than $5 \mathrm{~mm} .{ }^{1}$ Zhang et al reported that of a total of $112(\mathrm{n}=809$; $13.8 \%$ ) patients considered to have IMLN-positive diseases (the median size of the enlarged IMLN was $1.3 \mathrm{~cm}$ [range: $0.5-3.0 \mathrm{~cm}$ ]) on the basis of imaging reports, only ten patients underwent ultrasound-guided fine-needle aspiration to obtain pathologic confirmation and all of the sampled lymph nodes were confirmed to contain malignant cells before receiving chemotherapy. Patients with positive IMLN before NAC received adjuvant radiation to the breast or the chest wall and the regional lymphatics including the IMLN chain with a median dose of 60 Gy if the IMLNs normalized after chemotherapy and 66 Gy if they did not. ${ }^{4}$ However, some patients with positive IMLN could not be detected by imaging techniques and fine-needle aspiration could not be performed for all suspicious positive IMLNs under ultrasonographic guidance. High-risk did not mean IMLN metastases, and low-risk did not mean IMLN negative. Hence, we recommend internal mammary sentinel lymph node biopsy (IM-SLNB) as a minimally invasive technique for the efficient evaluation of the status of internal mammary sentinel lymph node (IM-SLN) to obtain complete nodal staging and guide adjuvant radiotherapy.

Sixty female patients who had histologically proven clinical stage T1 through T4, N0 through N3, M0 primary invasive breast cancer treated at the Breast Cancer Center in Shandong Cancer Hospital and Institute between 2012 and 2014 were enrolled in the study. Anthracycline- and taxane-based regimens were done. An amount of 18.5-37 MBq of ${ }^{99 m}$ Tc-labeled sulfur colloid in $1.0-1.2 \mathrm{~mL}$ volume was injected intraparenchymally at the 6 and 12 o'clock positions $2-3 \mathrm{~cm}$ away from the nipple under ultrasonographic guidance 3-18 hours before surgery in all patients. Subsequently,
Correspondence: Yong-Sheng Wang Breast Cancer Center, Shandong Cancer Hospital and Institute, No 440, Jiyan Road, Jinan, Shandong, 250II7, People's Republic of China

Email wangysh2008@aliyun.com 
lymphoscintigraphy was performed $0.5-1.0$ hours before surgery. IM-SLNB was performed on all patients with IM-SLN detected by preoperative lymphoscintigraphy or intraoperative gamma-probe. The IM-SLNB was performed from the sternal border in a lateral direction for 3-4 cm, and the pectoral major and minor muscle fibers were separated to expose the posterior intercostal space. The external and internal intercostal muscles were divided transversally from the sternal border. In this procedure, particular care must be taken to avoid injury to the inferior parietal pleura and internal mammary vessels. The visualization rate of IM-SLNB was $63.3 \%(38 / 60)$. The median age of the 38 patients was 50 years (range: $32-68$ years). The success rate of IM-SLNB was $97.4 \%$ (37/38). The median number of IM-SLNs was 2 (total 60, range: 1-4). The site of IM-SLNs concentrated in the second $(44.7 \%, 17 / 38)$ and third $(55.3 \%, 21 / 38)$ intercostal space. The median time consuming was 10 minutes (range: 5-30 minutes). The IM-SLN-positive rate was $8.1 \%$ $(3 / 37)$, and all of them combined with positive axillary lymph nodes. Only two patients had intraoperative surgical complications. One had an injury to pleura and another had an injury to the internal mammary artery. They were repaired intraoperatively with no pneumothorax on postoperative chest radiography and postoperative bleeding.

It is necessary to perform IM-SLNB after NAC to ascertain the nodal staging and pathological status as there were still $8.1 \%$ of patients with IM-SLNs metastases after
NAC. The visualization and success rates of IM-SLNB are acceptable. The 2015 National Comprehensive Cancer Network Breast Cancer Clinical Practice Guidelines ${ }^{5}$ recommended that internal mammary radiotherapy should be performed on those patients with clinically and pathologically involved IMLN. IM-SLNB could help to make clear the pathological status and provide an accurate indication of radiation to the internal mammary area in case of under-stage and under-/over-treatment.

\section{Disclosure}

The authors report no conflicts of interest in this communication.

\section{References}

1. Cong BB, Qiu PF, Wang YS. Internal mammary sentinel lymph node biopsy: minimally invasive staging and tailored internal mammary radiotherapy. Ann Surg Oncol. 2014;21(7):2119-2121.

2. Veronesi U, Cascinelli N, Bufalino R, et al. Risk of internal mammary lymph node metastases and its relevance on prognosis of breast cancer patients. Ann Surg. 1983;198(6):681-684.

3. van der Ent FW, Kengen RA, van der Pol HA, Povel JA, Stroeken HJ, Hoofwijk AG. Halsted revisited: internal mammary sentinel lymph node biopsy in breast cancer. Ann Surg. 2001;234(1):79-84.

4. Zhang YJ, Oh JL, Whitman GJ, et al. Clinically apparent internal mammary nodal metastasis in patients with advanced breast cancer: incidence and local control. Int J Radiat Oncol Biol Phys. 2010;77(4):1113-1119.

5. Gradishar WJ, Anderson BO, Balassanian R, et al. Breast cancer version 2. 2015. J Natl Compr Canc Netw. 2015;13:448-475. Available from: www.nccn.org/ patients. Accessed May 29, 2015.

Dove Medical Press encourages responsible, free and frank academic debate. The content of the OncoTargets and Therapy 'letters to the editor' section does not necessarily represent the views of Dove Medical Press, its officers, agents, employees, related entities or the OncoTargets and Therapy editors. While all reasonable steps have been taken to confirm the content of each letter, Dove Medical Press accepts no liability in respect of the content of any letter, nor is it responsible for the content and accuracy of any letter to the editor.

OncoTargets and Therapy

\section{Publish your work in this journal}

OncoTargets and Therapy is an international, peer-reviewed, open access journal focusing on the pathological basis of all cancers, potential targets for therapy and treatment protocols employed to improve the management of cancer patients. The journal also focuses on the impact of management programs and new therapeutic agents and protocols on

\section{Dovepress}

patient perspectives such as quality of life, adherence and satisfaction. The manuscript management system is completely online and includes a very quick and fair peer-review system, which is all easy to use. Visit http://www.dovepress.com/testimonials.php to read real quotes from published authors. 